\title{
O fundo do poço e as motivações da censura
}

\author{
Maria Cristina Castilho Costa \\ Doutora em Ciências Sociais (Antropologia Social) pela Universidade de São Paulo, onde é \\ livre-docente em Ciências da Comunicação pela Escola de Comunicações e Artes. Atualmente \\ é professora associada da Universidade de São Paulo, presidente da Comissão de Pesquisa da \\ ECA/USP, coordenadora do Curso de Especialização Lato Sensu Gestão da Comunicação e \\ editora da revista Comunicação \& Educação*.
}

E-mail: criscast@usp.br

\begin{abstract}
Resumo: $\mathrm{O}$ artigo faz uma análise do processo de censura prévia de O poço (1950), de Helena Silveira, sob guarda do Arquivo Miroel Silveira da ECA-USP. É a partir da oposição de caráter estético e político que podemos interpretar a impugnação de 0 poço, e de outros textos que apresentam e discutem criticamente aspectos e fatos da realidade social. O processo nos mostra, por um lado, as tendências de uma época e a resistência do status quo ao que era inovador, transformador, provocativo, desconhecido e inusitado - na metade do século $X X$, sob influência do que acontecia no mundo; e os censores estavam à procura desses sinais de subversão da ordem, da ideologia para combatê-las, mesmo que a classe artística em geral estivesse pronta para resistir. Por outro, o processo nos revela as trocas e influências entre os meios de comunicação, as linguagens, os autores e os artistas, apresentando imbricações novas e nem sempre devidamente reconhecidas.
\end{abstract}

Palavras-chave: Censura, teatro, arquivos, etnografia de arquivos, comunicação.
Abstract: This paper brings an analysis on the prior censorship process of the theater play The Well (O poço, 1950), by Helena Silveira, whose documents are filed in the Miroel Silveira Archives of ECA-USP. Going from the opposition between the aesthetical and political characteristics of the play, we can interpret the prohibition of The Well and of other works that critically introduce and discuss the social reality aspects and facts. On one hand, the documents show us trends of a time and the status quo strength to what was innovative, transformative, provocative, unknown and unused by the half of the $X X$ th century, under the influence of what was happening in the world. Censors were in search of those signals of subversion, of the ideology against the establishment, even if the artistic class in general was ready to resist. On the other hand, the proceedings show us exchanges and influences among media, languages, authors and artists, introducing new imbrications that are not always recognized.

Keywords: Censorship, theater, archives, ethnography of archives, communication
Recebido: 28.10.2010

Aprovado: 15.11 .2010

* É coordenadora do NPCC - Núcleo de Pesquisa em Comunicação e Censura da USP e do Projeto Temático - Comunicação e Censura - Análise teórica e documental de processos censórios a partir do Arquivo Miroel Silveira (ECA/USP), com apoio da FAPESP. 
comunicação \& educação • Ano XVI • número 1 • jan/jun 2011

continuaram a discutir a necessidade da liberdade de expressão e as tentativas de censura que, apesar da Constituição de 1988 ter abolido a censura no território nacional, parecem emergir aqui e acolá num arremedo de autoritarismo das instituições públicas e privadas. Nós, do Núcleo de Pesquisa em Comunicação e Censura da USP, queremos participar desse debate e mostrar a todos o que temos aprendido sobre o tema em nossas pesquisas. Este artigo é um estudo realizado sobre o processo de censura prévia a um espetáculo teatral apresentado em São Paulo, em 1950, o qual pode lançar luzes a respeito das intenções e critérios da prática da censura. Esperamos estar contribuindo para esclarecer os leitores sobre esse tema tão incômodo, delicado e necessário.

O Ministério da Justiça propõe-se a inquirir a população sobre critérios de classificação etária e sobre outras medidas de fiscalização dos meios de comunicação. Esse parece ser, portanto, o momento adequado para se analisar como, quando e por que houve censura no Brasil, em épocas muito recentes.

\section{ARQUIVO MIROEL SILVEIRA DA ECA-USP}

Quando o Arquivo Miroel Silveira chegou à Universidade de São Paulo, trazido, segundo a memória oral desse fato, numa caminhonete, era composto de vários volumes de couro verde encadernando, cada um com cerca de quinze processos de censura prévia ao teatro em São Paulo, de 1930 a 1970. Como presidente da Comissão de Biblioteca da ECA, iniciei a organização e pesquisa desse material. Os processos foram desencadernados e higienizados para, posteriormente, serem colocados em envelopes e pastas suspensas de estantes deslizantes. Conservam-se na mesma ordem numérica crescente, exibindo na capa que o recobre o brasão impresso de São Paulo e a sigla D.E.I.P. - relativa ao Departamento Estadual de Imprensa e Propaganda, braço estadual do DIP do Estado Novo de Getúlio Vargas -, e o Número do Prontuário e o título da obra, escritos a mão. O processo que vamos estudar neste artigo é o de Número 2946, referente à peça $O$ fundo do poço, de autoria da escritora Helena Silveira.

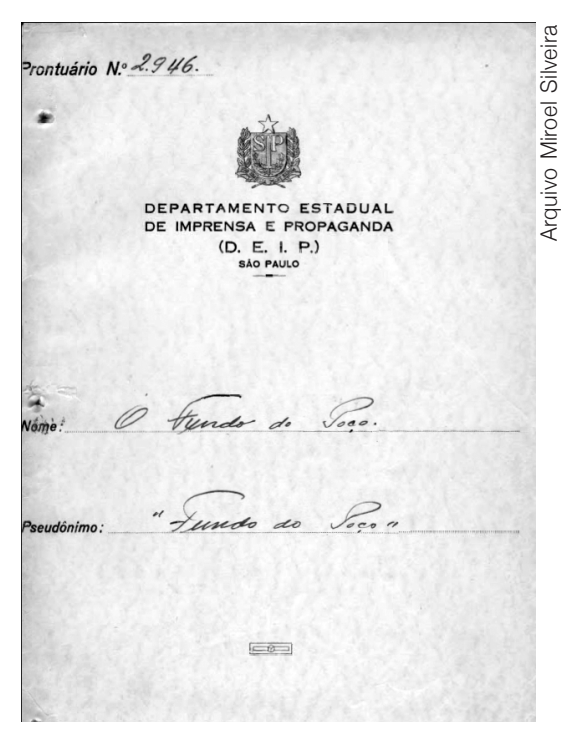

Como nos demais processos do Arquivo, o primeiro documento é a carta do produtor, diretor ou autor, endereçada ao Diretor da Divisão de Censura do Departamento de Diversões Públicas, solicitando o obséquio de proceder à censura da obra. No processo 2946, quem assina a carta é Sandro Polônio, 
O fundo do poço e as motivações da censura - Maria Cristina Castilho Costa

empresário, responsável pelo espetáculo que seria levado à cena em março de 1950, no Teatro de Cultura Artística de São Paulo, dirigido pelo requerente. O documento é datado de 2 de fevereiro do mesmo ano, o que mostra que os trâmites de liberação costumavam levar cerca de um mês. A peça identificada como em três atos e dez quadros, intitulava-se simplesmente $O$ poço. A correspondência tem firma reconhecida como exigia a regulamentação, tendo dado entrada na Secretaria de Segurança Pública a 4 de fevereiro, conforme carimbo do escriturário.

A segunda folha do processo contém quatro carimbos, um do Diretor do DDP, Joaquim Roller Souto, e outro assinado por dois censores impugnando a representação da peça, a 13 de fevereiro de 1950. Os demais são de arquivamento do processo. Os censores, conforme conta do parecer, foram Raul Fernandes Cruz e José Américo Cezar Cabral.

A terceira página do processo 2946 é um Ofício do Departamento de Investigações da Divisão de Diversões Públicas, da Secretaria de Estado dos Negócios da Segurança Pública, assinado pelo Diretor Souto, a 13 de fevereiro, solicitando que fosse dada ciência a Sandro Polônio da impugnação da peça. Em 15 de fevereiro, Graça Melo, diretor e ator do espetáculo, assina carta de próprio punho declarando estar ciente do Despacho. As duas páginas seguintes do processo são dedicadas ao parecer dos censores que iremos analisar mais detidamente.

Após o parecer, anexa-se ao processo carta de Sandro Polônio, datada de 18 de fevereiro, na qual o empresário pede reconsideração da decisão da censura, apresentando texto modificado, com novo título - O fundo do poço -, e constando como coautor da peça o marido da escritora Helena Silveira, Jamil Almansur Haddad. Novos carimbos certificam a reabertura do processo em 16 de março do mesmo ano. É importante lembrar que, já nessa época, mo-

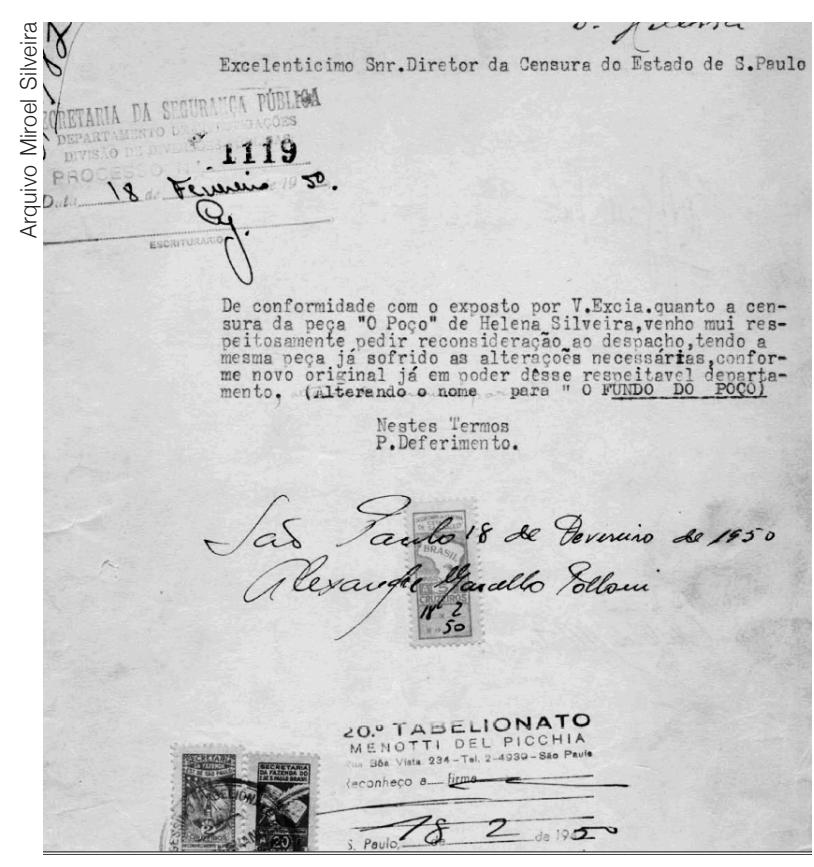

dificações no título e no texto eram recursos comuns nas solicitações de reconsideração. Algumas modificações nos títulos eram propostas pelos próprios censores - a peça Sindicato dos Malucos, de autoria de Ado Benatti, teve seu título alterado no próprio certificado de censura para Clube dos $M a$ lucos, no processo de número 0483, no ano de 1944.

Carta de Sandro Polônio, em que o empresário pede a reconsideração da decisão da censura, apresentando o novo título: O fundo do poço. 
comunicação \& educação • Ano XVI • número 1 • jan/jun 2011

É possível também que, além das modificações propostas no corpo da obra, provavelmente por Haddad, que agora aparece como coautor, o diretor e a atriz Maria Della Costa, que encenaria a peça, tenham procurado amigos e autoridades solicitando revisão e liberação da obra, como acontecia comumente quando se tratava de artistas de destaque e com boas relações na sociedade. O fato é que em 14 de março é expedido o certificado de censura liberando o espetáculo para maiores de dezoito anos, com cortes de falas em quinze páginas. Ao contrário dos demais processos, a cópia existente no Arquivo não indica os cortes exigidos e ficamos sem saber o que os censores propuseram omitir do texto.

Consta ainda do processo 2946 Nota Breve do Diretor, escrita à mão, na qual ele explica que a encenação previa dois planos distintos: o primeiro onde se passam cenas de tratamento realista em que tudo que ali ocorre "realmente acontece"; o segundo, de caráter expressionista, em cenas sem nenhum contato com a realidade. Acentua o diretor: nada do que ali se passa "realmente acontece" (grifos do autor). Continua Mello: "As figuras das 3 mulheres que aparecem neste plano são irreais e existem apenas na imaginação do personagem Julio e surgem tal como ele as vê, dentro do seu delírio de remorso e culpa".

Entenderemos mais adiante o sentido dessa breve nota.

\section{O FUNDO DO POÇO (OU O POÇO)}

A peça de Helena Silveira, presente no processo do Arquivo Miroel Silveira, é o original que foi impugnado pelos censores, conforme indica o carimbo constante da folha de rosto, com data de 7 de fevereiro. Trata-se de um drama familiar que, conforme texto introdutório, se desenrola em São Paulo, no tempo da sua encenação. Um cenário expressionista que procura mostrar pobreza e incúria:

Um corredor fundo e escuro deve desembocar na cena, em ligeiro declive. Trata-se de uma velhíssima casa térrea de frente para a rua. Na sala de jantar, clássica talha de água. Algumas cadeiras austríacas. Uma cadeira de balanço. Uma máquina de costura, um guarda-comidas de porta de tela de arame esburacada deixando ver seu ventre estripado de prateleiras desiguais e louça rachada. Uma janela mostrando trecho do quintal com varais onde secam roupas. Um mamoeiro. Muitas portas fechadas. Entretanto, o corredor tem as portas escancaradas e desemboca na cena como um túnel. Uma mesa tem a toalha cheia de nódoas, copos e pratos sujos, garrafa de cerveja vazia ${ }^{1}$.

A família que protagoniza o drama é composta da mãe, velha e doente Úrsula -, das duas filhas - Conceição e Cornélia - e do filho Julio. Os quatro vivem uma relação neurótica sob domínio da genitora beata, moralista e repressora. Os diálogos são tensos e remetem à atmosfera asfixiante da casa, cheia de cobranças pessoais e repreensões, lembrando o ambiente de $\grave{A}$ margem $d a$ vida, de Tennessee Williams, que estreara pouco antes em São Paulo, em 1947. Entretanto, em $O$ poço a ação se passa em dois tempos representados, conforme 
O fundo do poço e as motivações da censura - Maria Cristina Castilho Costa

indica a concepção cenográfica, por dois planos, um no qual os membros da família se enfrentam em sua solidão agressiva e ressentida, e outro quando, depois de ter assassinado a família, Julio, o filho muito amado, recebe a visita de inspetores policiais que investigam denúncias do crime. Toda a peça procura mostrar que relações neuróticas resultam em situações extremas - a mãe com um moralismo exacerbado, cheia de preconceitos contra as pessoas e amor incestuoso pelo filho; a filha Cornélia com a sexualidade reprimida, expressando seus desejos em estranhos sonhos premonitórios, e a tímida e reclusa Conceição, que também nutre pelo irmão um amor mórbido. O final dramático para essa relação depressiva é a morte anunciada por presságios que emergem nos diálogos entre os personagens. Ao perceber que a família se oporá ao seu casamento com a namorada - Ismênia -, Julio assassina as mulheres da família e depois, ameaçado de ver seu crime descoberto, se mata.

Os censores que analisaram a peça, após demorada leitura, conforme afirmam no parecer que acompanha o processo, impugnam a encenação baseados nos seguintes critérios: 1) O artigo 188 do Decreto 4.405-A, de 17 de abril de 1928, reza impedir a representação de peças que, por sugestão ou ensinamentos, possam induzir alguém à prática de crimes, ou contenham a apologia, direta ou indireta destes...; 2) $\mathrm{O}$ mesmo artigo proíbe a representação de peças que contenham ofensas à moral $e$ aos bons costumes - pormenor esse encontrado na peça em apreço, quando se refere à paixão que sente a irmã pelo próprio irmão; 3) A peça reproduz fielmente o crime da Rua Santo Antonio, bastante vivo na opinião pública; 4) Uma das personagens, Cornélia, tem quase o mesmo nome de uma das vítimas do aludido crime - Cordélia -, cuja troca de consoantes não desfaz a impressão auditiva que caracteriza a personagem; 5) Da leitura da peça não se chega à conclusão de fundo educativo de que o crime não compensa. Ao contrário, exorta-se a prática de crimes, alegando-se que a terra está pedindo mortos; 6) A encenação prevê a participação de menores de idade, o que infringe dispositivos legais.

É fácil perceber, por esse parecer, que os censores, numa leitura superficial e linear do texto, confundem conflitos psicológicos com exortação ao comportamento que esses conflitos engendram. Helena Silveira não justifica o assassinato de Julio, mas procura mostrar que relações mórbidas levam a desfechos trágicos. Como sustentou Oswald de Andrade, em crônica no jornal Folha da Manhã publicada à época, era intenção da autora recriar a atmosfera angustiantemente, repressora e neurótica de famílias e grupos que se fecham em torno de si mesmos, bem como a resistência que enfrentam aqueles que procuram, de alguma forma, se libertar dos grilhões dessa relação opressora. A saída, segundo a autora, muitas vezes, é o suicídio ou a morte.

Essa leitura superficial dos censores vem marcada pela tradição censória que, desde sempre, procurou encontrar nas palavras, nas expressões e nos diálogos o conteúdo explícito das intenções dos autores. Os diversos textos cortados e transformados, presentes nos processos do Arquivo Miroel Silveira, comprovam essa atitude rasa dos funcionários da censura, incapazes de pensar por meio de metáforas, jogos de palavras ou frases com duplo sentido. Portanto, julgar 
2. MIOLA, Mauro; VILLARI, Tito. Os tarados da Vila Ema. Parte integrante do Prontuário 3120 do Arquivo Miroel Silveira da ECA/USP.

3. BOAL, Augusto. Filha moça. Parte integrante do Prontuário 4178 do Arquivo Miroel Silveira da ECA/USP. que a autora, ao invés de condenar as relações opressoras que levam a fins dramáticos, estaria exortando ao crime, vem ao encontro de tudo que temos lido em termos de avaliação censória.

O que merece análise mais detida nesse parecer, entretanto, é a justificativa do veto em razão de a peça fazer referência a um crime de grande repercussão havido na cidade. Esse argumento aparece também em outros processos do Arquivo Miroel Silveira. Em 1951, o censor Liz Monteiro escreve em seu parecer que a peça Os tarados da Vila Ema, de Mauro Miola e Tito Villari, com colaboração de Daniel Bocci e João Kiss, deve ser impugnada porque: "O original apresentado para a Censura não tem o menor conteúdo teatral, artístico ou dramático. Trata-se de uma mera compilação dos noticiários de jornal, referentes ao escabroso drama policial registrado há pouco em Vila Ema, nesta cidade"”.

Em outros processos, censores voltam a condenar o realismo de cenas que lhes parecem ultrajantes e até mesmo obscenas, como escrevem em seus pareceres, por remeterem a uma realidade que, ao contrário de ser levada aos palcos, deveria ser evitada e esquecida. Para entendermos essa atitude, precisamos lembrar que, na metade do século XX, duas tendências estéticas se opunham na produção artística: o realismo, presente nas obras artísticas de proposta social e politicamente engajadas, com críticas e denúncias às injustiças sociais, e o idealismo, utilizado nas obras mais conservadoras, de cunho educativo ou moral. É a partir dessa oposição de caráter estético e também político que podemos interpretar a impugnação de $O$ poço, assim como de outros textos que procuram apresentar e discutir criticamente aspectos e fatos da realidade social. Procurando sempre evitar referências ao poder estabelecido, críticas às autoridades políticas, denúncias à realidade social, os censores viam com maus olhos as referências explícitas a acontecimentos reais. É assim que critérios estéticos se confundem com pressupostos morais, ideológicos e políticos. Seja qual for a referência que se faça à realidade, a obra de arte, ficcional ou não, é sempre suspeita de fazer crítica e oposição à situação vigente.

Comprovando essa postura estética e política dos censores dessa época, no processo 4178, datado de 1956, referente à peça Filha moça, de Augusto Boal, o censor Marcio de Assis Brasil defende a impugnação da encenação afirmando que, após leitura cuidadosa do original, nada encontrou de aproveitável. Em seu parecer lembra: "O teatro é escola. E nessa peça tudo é negativo. Precisamos aprimorar os costumes. Aprimorar os sentimentos. Aprimorar a linguagem. Não será com peças desse estofo que se vai conseguir tal aprimoramento"3.

Dessa forma, com uma análise superficial do texto e um idealismo rasteiro em relação ao conteúdo e à forma da dramaturgia, os censores de $O$ poço não conseguiram perceber que os diálogos expressando os sentimentos íntimos e paranoicos dos personagens eram uma forma de condená-los. E, confundindo a referência à vida real como uma crítica política à sociedade estabelecida, optaram, sem qualquer dúvida, pela impugnação da peça. Em vista disso, terminam seu parecer dizendo: 
O fundo do poço e as motivações da censura - Maria Cristina Castilho Costa

Outrossim, tomamos a liberdade de lembrar a V. S. a conveniência de esta medida ser comunicada ao Serviço de Censura Federal, a fim de que, lá, por não conhecerem o âmago do assunto em apreço, evitem aprová-la com cortes ou outras restrições (grifo dos autores) ${ }^{4}$.

Referiam-se eles ao fato de que o crime, tendo ocorrido em São Paulo, provavelmente, não seria de conhecimento dos censores do Rio de Janeiro.

\section{O CRIME DA RUA SANTO ANTONIO}

Helena Silveira, prima de Miroel Silveira e de Dinah Silveira de Queiroz, foi contista, cronista e dramaturga. Trabalhou no Suplemento Literário da Folha da Manhã, escreveu colunas sociais com o pseudônimo Helen e foi crítica de televisão e telenovela, tendo escrito ensaios de grande interesse sobre esse veículo que se tornava um dos mais importantes meios de comunicação da época. Foi membro da Associação Brasileira de Escritores e recebeu o prêmio Alcântara Machado por seu livro de contos Mulheres. Sua obra mais polêmica, entretanto, foi $O$ poço, peça que teve, como vimos, colaboração de seu marido. Helena Silveira era uma autora inovadora e sem medo de enfrentar os desafios de sua época, fossem eles analisar programas e artistas de televisão ou abraçar as causas políticas que envolviam e estimulavam os intelectuais de então. Ousadas e sem preconceitos eram suas atitudes, como criar um troféu para produções televisivas que, em sua homenagem, levaram seu nome. A cada ano, o Troféu Helena Silveira era esperado por artistas da televisão acostumados a encontrar, por parte de outros críticos, toda espécie de preconceito e pouco caso em relação ao seu trabalho na televisão.

Com esse perfil, é compreensível que essa escritora tenha acompanhado toda a mobilização da sociedade em torno do triplo crime ocorrido na Rua Santo Antonio, na Bela Vista (ou Bixiga), em São Paulo, em 1948. Como

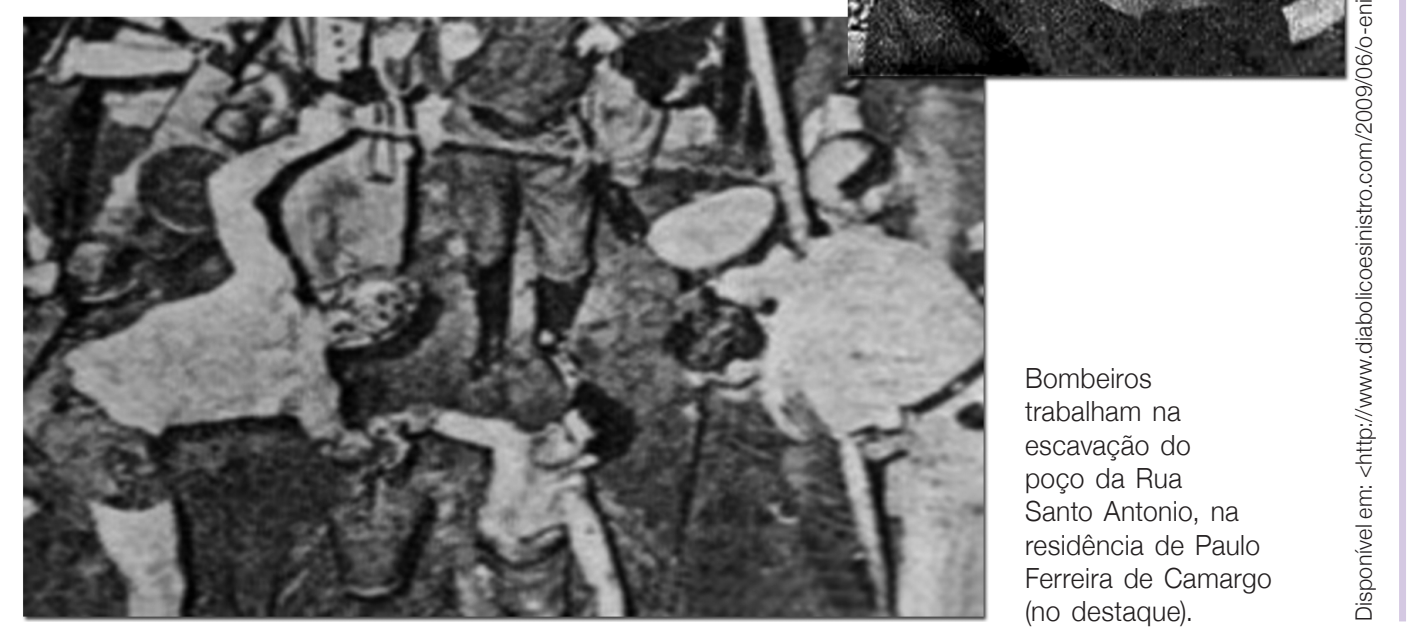

4. SILVEIRA, Helena. O poço. Parte integrante do Prontuário 2946 do Arquivo Miroel Silveira da ECA/USP. 
relatam documentos da época, um professor de química e doutorando da Universidade de São Paulo, Paulo Ferreira de Camargo, assassinou a tiros a mãe e as duas irmãs, jogando-as em um poço no quintal de sua casa, de cabeça para baixo e vestindo mortalhas que ele mesmo teria pedido para a mãe confeccionar. Vizinhos, que suspeitaram do comportamento duvidoso desse moço de 26 anos, levaram a polícia a investigá-lo. Quando inquirido sobre o crime, Paulo se suicidou com um revólver, no banheiro de sua casa, no exato momento em que a polícia destampava o poço para retirar os cadáveres. O crime teve grande repercussão social e a cidade, consternada, acompanhou atentamente o noticiário.

As aproximações entre jornalismo e dramaturgia não são raras - Nelson Rodrigues, um dos escritores mais talentosos e inovadores da década de 1940, foi repórter policial antes de se revelar dramaturgo. Suas peças abordavam o mundo conturbado dos criminosos e de suas intenções mais recônditas. O resultado foi uma verdadeira revolução na dramaturgia brasileira à qual foi sensível Zbigniew Marian Ziembinski, diretor polonês, igualmente revolucionário, que levou aos palcos Vestido de noiva, daquele autor, verdadeiro marco do teatro moderno no Brasil. Helena Silveira, atenta à produção artística de seu tempo, deve ter sido sensível a essa maré renovadora, assim como às peças estrangeiras que começavam a ser traduzidas e encenadas no país, expondo conflitos psicológicos e personagens contraditórios, como a mencionada peça $\grave{A}$ margem da vida, de Tennessee Williams. Mas, como Nelson Rodrigues, Helena Silveira esbarrou com a tradição censória para a qual o teatro devia ser educativo, moral e idealista, sendo passível de veto qualquer proposta realista, crítica ou denunciadora que passava, automaticamente, a ser considerada subversiva para uma censura conservadora e passadista.

Sua ousadia, entretanto, lhe valeu um processo movido pela família das vítimas do crime, bem como a constante perseguição dos censores. A 30 de março de 1950, treze dias após a estreia, os dois censores Raul Cruz e José Américo Cabral escrevem ao Diretor do Serviço de Censura a seguinte carta:

Em virtude de os responsáveis pelo Teatro Dramático que ora se apresenta no Teatro de Cultura Artística com a peça O fundo do poço, de autoria de Helena Silveira, não terem observado os cortes que esta divisão impôs à representação da referida peça, e isso apesar dos reiterados avisos verbais que lhes foram feitos e apesar, ainda, de notificados nesse sentido pelo Serviço de Fiscalização desta Divisão, do que tomou ciência verbal o Secretário da Companhia, propomos a V. S. a penalidade cabível no caso e, as reincidências, a impugnação imediata das representações do citado argumento ${ }^{5}$.

5. Ibid.

6. BRANDÃO, Tânia. Uma empresa e seus segredos: Companhia Maria Della Costa. São Paulo: Perspectiva; Rio de Janeiro: Petrobrás, 2009.
Tânia Brandão, no livro sobre a Companhia Maria Della Costa ${ }^{6}$, revela que a recepção do texto foi polêmica e que a crítica, apesar de elogiar a atriz e a autora, considerou que o texto publicado pela Editora Martins era melhor que sua encenação. Brandão menciona ainda que a autora reconheceu ter feito pequenas mudanças no original, como a troca do nome da personagem Cornélia por Cristina, como sugerira o censor. 
O fundo do poço e as motivações da censura - Maria Cristina Castilho Costa

Oswald de Andrade, em sua coluna Telefonema, já havia defendido a obra mesmo antes de ser encenada. Escreveu ele, em 17 de junho de 1949:

A cidade que produz um grande crime pode dar uma grande literatura. Disso me convenci mais uma vez lendo agora os originais de uma peça de Helena Silveira, intitulada $O$ poço. Ela criou, em torno do tremendo caso da Rua Santo Antonio, qualquer coisa de novo e de especial em nosso teatro ${ }^{7}$.

Entretanto, conforme menção de Sábato Magaldi e Maria Tereza Vargas no livro Cem anos de teatro em São Paulo, a estreia de O fundo do poço se deu sob protestos $^{8}$.

\section{VOLTANDO AO ARQUIVO}

Se, como afirmou Farge, o arquivo é uma brecha no tecido dos dias, o processo de censura prévia de $O$ fundo do poço (ou $O$ poço) é especialmente interessante pelas suas intertextualidades e interfaces. Por um lado nos mostra as tendências de uma época e a resistência do status quo em relação ao que era inovador, transformador, provocativo, desconhecido e inusitado - na metade do século $\mathrm{XX}$, sob influência do que acontecia no mundo e da bagagem que imigrantes, como Ziembinski, traziam para o país, a produção artística se renovava. Os censores estavam à procura desses sinais de subversão da ordem, da ideologia e do gosto para combatê-los ou atrasá-los. Mas os autores, os diretores e os artistas em geral estavam prontos para resistir.

Por outro lado, o processo nos revela as trocas e influências entre os meios de comunicação, as linguagens, os autores e os artistas, apresentando imbricações novas nem sempre devidamente reconhecidas. É a imprensa influenciando a arte que responde, provoca, analisa, aproximando a ficção da realidade, o noticiário da encenação.

$\mathrm{O}$ arquivo congela o instante e possibilita o desconstruir de suas sequências, enunciados, enredo. Expõe processos, indica presenças, nomeia testemunhas, dita veredictos, resgata memórias. Finalmente, o arquivo subentende, nas entrelinhas, o público anônimo, a sociedade com seus medos, preconceitos e expectativas. Eles aparecem como a sociedade, o público, os espectadores, em nome de quem se justifica a batalha que se trava entre artistas e censores.

E como saber o que sentia o público, quando estreou a peça e foi encenado o crime que comoveu São Paulo? Para obter essa resposta, abrimos outros arquivos - o das memórias pessoais publicadas em diferentes sites na Internet referentes à cidade de São Paulo e a seus acontecimentos. Encontramos inúmeras menções ao crime da Rua Santo Antonio postadas por testemunhos pessoais que, com suas lembranças, comprovam ter sido este um dos crimes que mais abalaram o público. Pessoas se referem a ele, contam detalhes, dizem ter visitado o local, na época, postam fotografias e afirmam ter acompanhado diariamente as notícias nos jornais. À peça só se referem os especialistas, os críticos e os biógrafos. A censura cumpriu seu papel e, ao que consta, $O$ poço não foi reencenado nunca mais.
7. ANDRADE, Oswald. O telefonema. São Paulo: Globo, 2007. p. 446.

8. MAGALDI, Sábato; VARGAS, Maria Tereza. Cem anos de teatro em São Paulo. São Paulo: SENAC, 2000. p. 248. 
comunicação \& educação • Ano XVI • número 1 • jan/jun 2011

Apesar disso, o imaginário popular continuou tecendo seu próprio enredo - a casa onde o Crime do poço aconteceu ficou longos anos desabitada e o terreno foi considerado maldito. Mais tarde, a construção foi demolida junto a outras do quarteirão, numa grande empreitada que deu origem a um alto edifício, famoso na paisagem do centro da cidade, perto do Vale do Anhangabaú, chamado Joelma. Este também, entretanto, teve um fim trágico, tendo sido destruído, em 1974, por um grande incêndio, fato este que veio alimentar ainda mais os sentimentos de desconfiança e medo da população que viu no desastre mais um sinal da antiga maldição.

Roberto Stavale, testemunha ocular de todos esses acontecimentos, publicou no site Usina de Letras um longo depoimento sobre as tragédias do Bixiga, bairro onde morava.

"Em meio a tantos folclores sobre o local das tragédias (referia-se ao terreno da Rua Santo Antonio que deu lugar ao Edifício Joelma), devemos lembrar a frase de William Shakespeare: Há mais coisas entre o céu e a terra do que sonha nossa vã filosofia." ${ }^{9}$

A nós só resta terminar dizendo que, felizmente, contra o imaginário popular e anônimo nunca houve censura capaz de cortar, remendar ou silenciar. Enquanto $O$ poço, de Helena Silveira, repousa no envelope de número 2946, nas pastas de um arquivo histórico, a versão popular corre solta pelas redes sociais em busca de interessados. Os censores ficariam surpresos em constatar que, assim como a peça vetada, a opinião pública e o imaginário da população também têm sua origem na realidade.

\section{REFERÊNCIAS BIBLIOGRÁFICAS}

ANDRADE, Oswald. O telefonema. São Paulo: Globo, 2007.

BOAL, Augusto. Filha moça. Parte integrante do Prontuário 4178 do Arquivo Miroel Silveira da ECA/USP.

BRANDÃO, Tânia. Uma empresa e seus segredos: Companhia Maria Della Costa. São Paulo: Perspectiva; Rio de Janeiro: Petrobrás, 2009.

COSTA, Maria Cristina Castilho. A censura em cena. São Paulo: Edusp/Imprensa Oficial/Fapesp, 2006.

Etnografia de arquivos: entre o passado e o presente. Matrizes (USP. Impresso), v. 3, 2010.

DERRIDA, Jacques. Mal de arquivo: impressão freudiana. Rio de Janeiro: Relume

9. STAVALE, Roberto. O local das tragédias. Disponivel em: <http://www. usinadeletras.com.br/ exibelotexto. php?cod= 52288 \& cat $=$ Artigos $>$ Acesso em: 25 out. 2010.
Dumará, 2001.

FARGE, Arlette. O sabor do Arquivo. São Paulo: Edusp, 2009.

FOUCAULT, Michel. Aarqueologia do saber. Rio de janeiro: Forense Universitária, 1995 . 
O fundo do poço e as motivações da censura - Maria Cristina Castilho Costa

MAGALDI, Sábato; VARGAS, Maria Tereza. Cem anos de teatro em São Paulo. São Paulo: Senac, 2000.

MIOLA, Mauro; VILLARI, Tito. Os tarados da Vila Ema. Parte integrante do Prontuário 3120 do Arquivo Miroel Silveira da ECA/USP.

PORTO, Nuno. O museu e o arquivo do Império. In: BASTO, Cristiana; ALMEIDA, Miguel Vale de; FELDMAN-BIANCO, Bela. Trânsitos coloniais: diálogos críticos luso-brasileiros. Campinas (SP): Unicamp, 2007.

SILVEIRA, Helena. O poço. Parte integrante do Prontuário 2946 do Arquivo Miroel Silveira da ECA/USP.

\section{Endereços eletrônicos}

CARVALHO, Neuza Guerreiro de. Lendas Urbanas - a cidade e seus personagens: um crime hediondo em São Paulo. Disponível em: <http://www.vivasp.com/ texto.asp?tid=4472\&:Sid=9>. Acesso em: 26 out. 2010.

São Paulo - 1949: a cidade ainda é tranquila e um acontecimento. Disponível em: <http://www.saopaulominhacidade.com.br/list.asp?ID=369> . Acesso em: 26 out. 2010.

STAVALE, Roberto. Local de tragédias. Disponível em: $<$ http:/ / www.usinadeletras. com.br/exibeelotexto.php?cod=52288\&cat=Artigos $>$. Acesso em: 26 out. 2010. 


\section{Assine a revista Comunicação \& Educação}

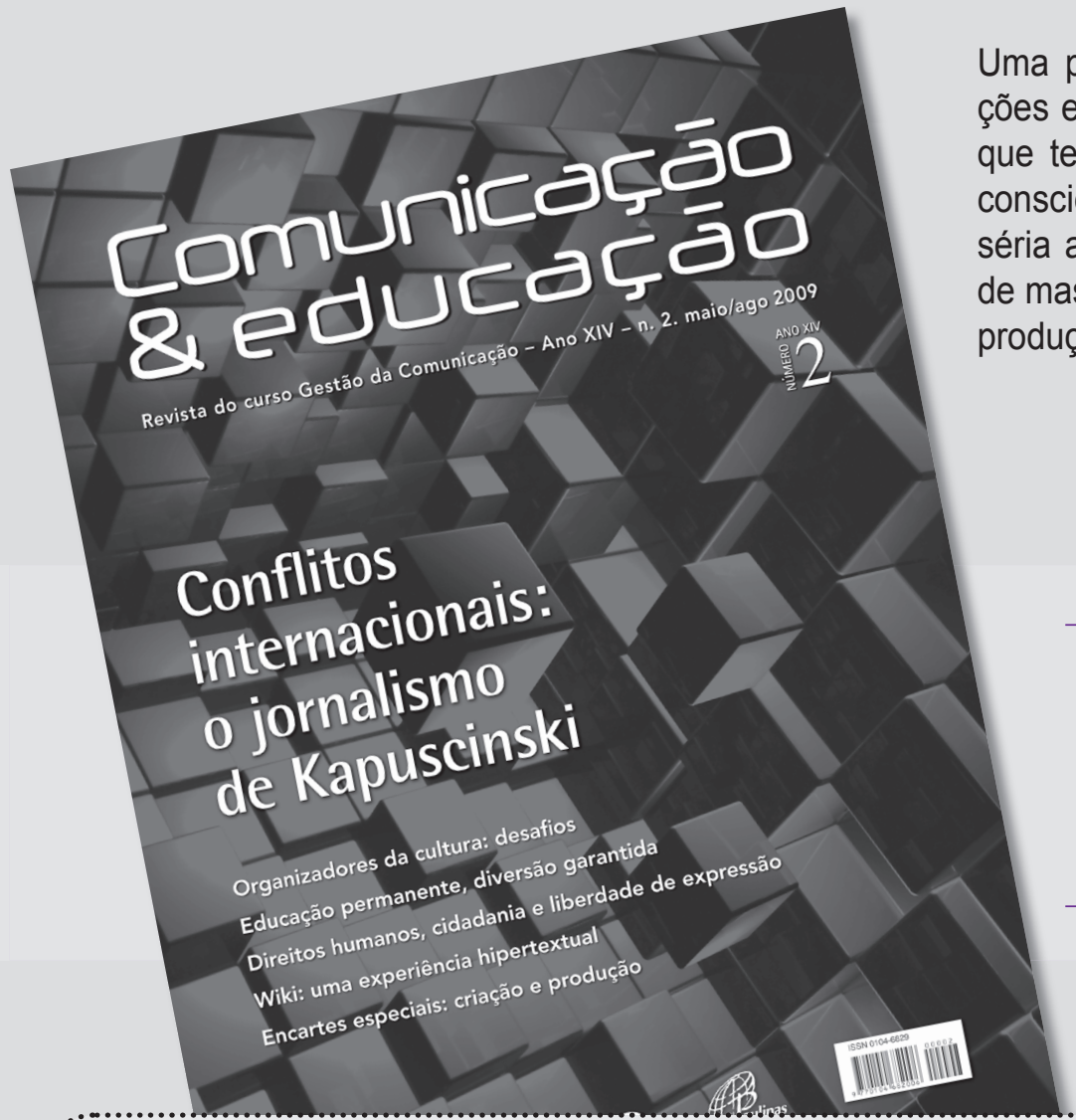

Uma parceria de Paulinas com a Escola de Comunicações e Artes, da Universidade de São Paulo (ECA-USP), que tem por objetivo ajudar a formar profissionais mais conscientes, críticos e interativos, por meio da discussão séria a respeito da natureza dos meios de comunicação de massa, dos direitos da audiência e da crítica estética à produção midiática.

\section{Revista Comunicação \& Educação \\ Periodicidade: semestral}

\section{Ensaios, entrevistas e debates com os maiores especialistas da área auxiliam educadores a incluir em suas práticas novas linguagens e novos recursos pedagógicos.}

\section{ADQUIRA TAMBÉM OS EXEMPLARES AVULSOS!}
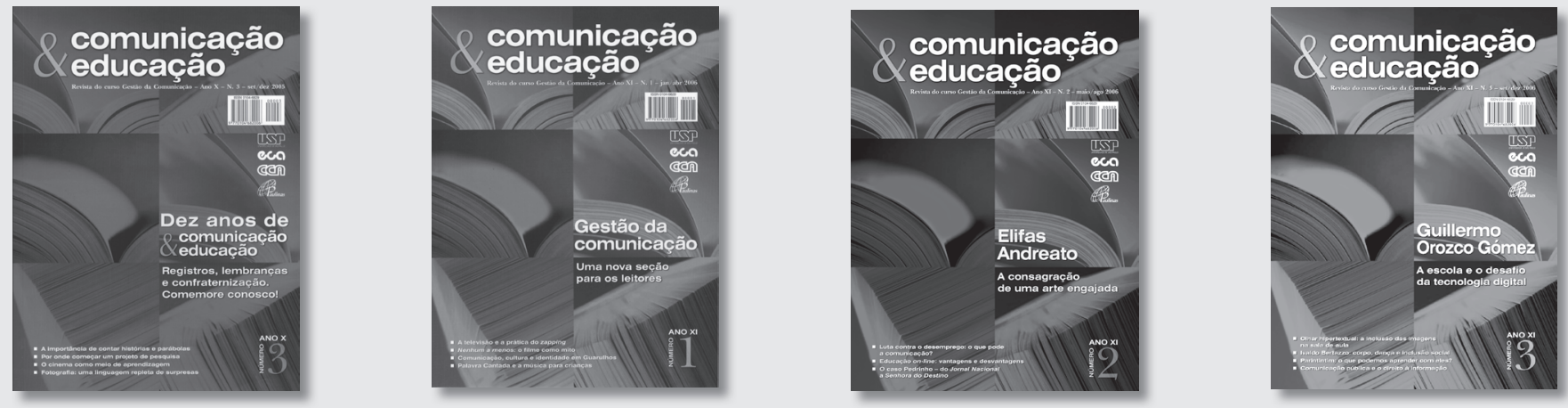

\section{VOCÉ ESCOLHE COMO QUER PAGAR!}

- Cartão de crédito - Visa, Mastercard ou Dinners • Boleto bancário

- Depósito bancário identificado • DOC ou transferência bancária

Ligue 0800-7010081 ramal 9448 ou assine

pela livraria virtual Paulinas, acessando www.paulinas.org.br Informações: livirtual@paulinas.com.br 